Kairos. Journal of Philosophy \& Science 20, 2018 Center for the Philosophy of Sciences of Lisbon University

\title{
Metaphysics, Function and the Engineering of Life: the Problem of Vitalism
}

\author{
Cécilia Bognon-Küss \\ IHPST/U. de Paris 1 Panthéon-Sorbonne/ \\ U. de Paris 4 Sorbonne \\ cecilia.bognon@gmail.com
}

Bohang Chen

Ghent University chenbh07@gmail.com

Charles T. Wolfe (corresponding author) Ghent University/CEU ctwolfe1@gmail.com

\begin{abstract}
Vitalism was long viewed as the most grotesque view in biological theory: appeals to a mysterious life-force, Romantic insistence on the autonomy of life, or worse, a metaphysics of an entirely living universe. In the early twentieth century, attempts were made to present a revised, lighter version that was not weighted down by revisionary metaphysics: "organicism". And mainstream philosophers of science criticized Driesch and Bergson's "neovitalism" as a too-strong ontological commitment to the existence of certain entities or "forces", over and above the system of causal relations studied by mechanistic science, rejecting the weaker form, organicism, as well. But there has been some significant scholarly "push-back" against this orthodox attitude, notably pointing to the 18th-century Montpellier vitalists to show that there are different historical forms of vitalism, including how they relate to mainstream scientific practice (Wolfe and Normandin, eds. 2013). Additionally, some trends in recent biology that run counter to genetic reductionism and the informational model of the gene present themselves as organicist (Gilbert and Sarkar 2000,
\end{abstract}

Ә Open Access. (C) 2018 C. Bognon-Küss, B. Chen, Ch.T. Wolfe, published by Sciendo. (cc) BY-NC-ND This work is licensed under the Creative Commons Attribution-NonCommercial-NoDerivatives 4.0 License. 
Moreno and Mossio 2015). Here, we examine some cases of vitalism in the twentieth century and today, not just as a historical form but as a significant metaphysical and scientific model. We argue for vitalism's conceptual originality without either reducing it to mainstream models of science or presenting it as an alternate model of science, by focusing on historical forms of vitalism, logical empiricist critiques thereof and the impact of synthetic biology on current (re-)theorizing of vitalism.

Keywords Vitalism, organicism, metaphysics, logical empiricism, synthetic biology.

DOI 10.2478/kjps-2018-0006

\section{Introduction}

Vitalism was long considered to be the most grotesque view in the spectrum of biological theories: an appeal to a mysterious life-force, Romantic insistence on the autonomy of the living, or worse, a metaphysics of an entirely living universe. It traditionally served as a foil for both biology and philosophy, being attached to metaphysical and nondeterministic claims, i.e. the hypothesis of nonmaterial vital forces governing the generation, development and vital functions in living beings. Depicted as a chronic epistemological disease, or an "obstacle épistémologique" as Bachelard' would have put it, nonmaterial vitalism has been harshly criticized by philosophers: mainstream philosophers of science, but also, Mikhail Bakhtin ${ }^{2}$ have justifiably criticized the "neovitalism" of Hans Driesch (discussed in section 3 below) and Henri Bergson ${ }^{3}$ as a too-strong ontological commitment to the existence of certain entities or "forces", over and above the system of causal relations studied and modeled by mechanistic science, which itself seeks to express these entities or the relations between them in mathematical terms.

Such philosophers also tended to reject the weaker form of this view, organicism, which was popular in the emerging theoretical biology of the time, ${ }^{4}$ despite the attempts that were made in the early twentieth century to present a revised, lighter version of vitalism that was not weighted down by revisionary metaphysics (in P.F. Strawson's sense of

$1 \quad$ Bachelard 1938.

2 Bakhtin 1926 [1992].

3 On the Bergsonian dimension, see Wolfe and Wong 2014 and Wong 2016.

4 Peterson 2010, Peterson 2017. 
a metaphysical program aiming, not just to describe the world but to revise our understanding of it, notably by "adding" to it, typically in the case of self or agency, but in this case, of vital forces or powers ${ }^{5}$ ). We will return to organicism below but to dispel any initial ambiguities, we use this term to refer to family of theories and models, in theoretical biology and philosophy of biology, which seek to describe laws or properties specific to organic life, without particular metaphysical baggage inasmuch as this is possible.

Thus in this context, vitalism is typically understood as the view at the utmost margins of the development of modern biology, that life is somehow to be understood as possessing a mysterious "vital force" or "vital principle", apart from the causal, experimental world studied by natural science. Thus Francis Crick could predict, in full genocentric self-confidence, in his 1966 Of Molecule and Men: "To those of you who may be vitalists, I would make this prophecy: what everyone believed yesterday, and you believe today, only cranks will believe tomorrow." 6 Indeed, vitalism, broadly understood as the commitment to the existence of irreducible vital properties or dispositions seems to have constantly been challenged - and threatened - by the development of chemistry and the possibility to reduce biological processes to a set of physico-chemical reactions. In the last decade, a novel and powerful take on the nature of life emerged, at the interplay of molecular biology and computer science, namely "synthetic biology", whose avowed goal is to produce living systems by means of their constituents (in bottom-up or top-down approaches), endowed with basic living processes (discussed in section 4 below). It seems at first view that the successes of synthetic biology would mean the defeat of any vitalist view.

However, there has been some significant scholarly push-back against this orthodox attitude, notably pointing to the Montpellier vitalists of the $18^{\text {th }}$ century, and emphasizing that there are different historical forms of vitalism, including in their relation to the mainstream practice of sci-

$5 \quad$ The descriptive metaphysician has the more modest task of elucidating our existing conceptual schema while the revisionary metaphysician has the speculative task of inventing a new conceptual schema (see Strawson 1959, Preface); "Revisionary metaphysics seeks to change our ways of thought in directions it finds necessary" (Blackburn 2003, 61).

6 Crick 1966, 99. 
ence. ${ }^{7}$ It resulted in an effort to contextualise the idea of vitalism within a "historical epistemology" of the life sciences, yielding historical distinctions between, e.g., Montpellier vitalism (associated with prominent $18^{\text {th }}$-century doctors and professors at the Montpellier Faculty of Medicine) and a more embryology-based vitalism in Germany with Johann Friedrich Blumenbach ${ }^{8}$ and Hans Driesch in the $19^{\text {th }}$ and early $20^{\text {th }}$ centuries. ${ }^{9}$ Here, vitalism is the name for a theory which seeks to do justice to the specificity of certain types of entities in a more naturalistic context; these entities can be variously defined or polarized as living versus dead bodies, physiological versus anatomical objects of study, organisms versus machines, and so on. In parallel to this reevaluation of vitalism by historians of science, some trends in recent biology that run counter to genetic reductionism and the informational model of the gene, place themselves under the heading of this concept which they prefer to name organicism. ${ }^{10}$

What happens if we return to the challenge of the anti-vitalist arguments formulated by the Vienna Circle and its successors, and look at vitalism in the twentieth century and today, not just as a historical form but as a significant metaphysical and/or scientific model? Is it possible to grasp some of the conceptual originality of vitalism without either (a) reducing it to mainstream mathematicocentric models of science (in a kind of "victors' narrative" in which proper science is formalizable, mathematically specifiable research) or (b) just presenting it as an alternate model of science? In other words, without either normalizing it or projecting a kind of "weak messianic power" onto its supposed abnormality, in which organicist-type thinking recurs despite successive mechanistic, genetic and otherwise reductive demystifications? ${ }^{11}$ In this paper we sketch three responses to the above problem: (i) a "historicist" argument that if one takes seriously the diversity of forms of vitalism, it becomes

\footnotetext{
$7 \quad$ The topic of Wolfe and Normandin, eds. 2013.

8 Blumenbach 1791.

9 See Duchesneau and Cimino eds. 1997 and Gambarotto 2018. On vitalism in early $20^{\text {th }}$-century thought see Nouvel ed. 2011 , Wolfe and Normandin eds. 2013.

10 Gilbert and Sarkar 2000, Moreno and Mossio 2015; discussion in Wolfe 2014.

11 Wolfe 2014, 2015.
} 
impossible to sustain "true/false" judgments about vitalism as such, minimally, and further, it becomes possible to conceive of more naturalistic, less metaphysical forms of vitalism (section 2); (ii) a comparative argument about the concepts of atom and entelechy in logical empiricist critiques of vitalism, showing that there is a way of evaluating Driesch's doctrine of entelechy as a non-metaphysical doctrine (section 3); (iii) a "presentist" argument in which we refute the idea that a synthetic and engineering approach to life would definitely refute any form of vitalism (section 4).

\section{The Enlightenment: Structural-Functional Vitalism}

The great French clinician and theorist of the early nineteenth century Xavier Bichat wrote that the Montpellier physicians, that is, the physicians associated with the Faculty of Medicine at the University of Montpellier in the second half of the eighteenth century, "considered science philosophically; they would have made greater [scientific] progress if they had known more anatomy."12 Yet when we consider the body of writings produced by the "Montpellier vitalists" (the term "vitalist" is first used widely in French to refer to this school), including Théophile de Bordeu, Jean-Joseph Ménuret de Chambaud, Henri Fouquet, Paul-Joseph Barthez, we find almost no traces of such metaphysically laden vital forces. They are not metaphysicians of life but médecins-philosophes seeking to model concepts of organism, or as they would have put it, the "animal economy," which can be understood as a predecessor term of "organism". Following the fundamental work of Rey, Duchesneau et al. and Williams, ${ }^{13}$ who have done much to put it on the map, we have argued elsewhere ${ }^{14}$ that the Montpellier vitalist school expresses a "structural-functional" form of vitalism, with the celebrated image of the bee-swarm (found in Maupertuis, Bordeu, Diderot and also Ménuret de Chambaud) expressing the structural relation between one life and many lives.

12 X. Bichat, Discours sur l'étude de la physiologie, included in Bichat 1800.

13 Rey 1987/2000; Duchesneau et al. 1997; Williams 2003.

14 Wolfe and Terada 2008, Wolfe 2010, 2015. 
In his article on "Observation" in the Encyclopédie, Ménuret mentions the bee-swarm and Bordeu in order to emphasize that life in the body occurs, or is best described as, a "connection of actions" ("Iiaison d'actions"):

"One could, following these authors, compare man to a flock of cranes which fly together, in a particular order, without mutually assisting or depending on one another. The Physicians or Philosophers who have studied and carefully observed man, have noticed this sympathy in all animal movements - this constant and necessary agreement in the interaction of the various parts, however disparate or distant from one another; they have also noticed the disturbance of the whole that results from the sensory disagreement of a single part. A famous physician (M. de Bordeu) and an illustrious physicist (M. de Maupertuis) likewise compared man, from this luminous and philosophical point of view, to a swarm of bees which strive together to hang to a tree branch. One can see them pressing and sustaining one another, forming a kind of whole (une espèce de tout), in which each living part contributes in its way, by the correspondence and direction of its movements, to sustain this kind of life of the whole body, if we may refer in this way to a mere connection of actions (liaison d'actions). ${ }^{15}$

What the "vitalist" Ménuret is doing here with the bee-swarm metaphor for the animal economy (or "organism" in our vocabulary) is asserting a structural, relational, positional approach to what makes living bodies unique. One should also note the presence of (partly) mechanistic language in his descriptions (more than in Bordeu's for instance), with the language of "springs" (ressorts). Similarly, one should note that even if we are faced with a form of holism here (as the idea of a "Life" composed of smaller "lives" makes explicit), it is a holism where componential analysis, that is, analysis of the properties of the parts, still plays a role. In that sense, not only is the form of vitalism expressed in the above passages

15 Ménuret $1765,318 \mathrm{~b}-319 \mathrm{a}$. 
far removed from claims about mysterious vital forces; this structural-functional approach to life is also closer to materialism than is often said, if we notice the appeal to a kind of vital materiality.

The structural-functional understanding of living systems, again, does not appeal to a special "substance" to define them, but rather to what von Bertalanffy would have called in the twentieth century, an "organizational" understanding: "There is no 'living substance' because the characteristic of life is the organization of substances." 16 In his fascinating and quite programmatic article in the Encyclopédie on the notion of "animal economy", Ménuret defines the latter term as "l'ordre, le méchanisme, l'ensemble des fonctions $\&$ des mouvemens qui entretiennent la vie des animaux." This is neither a strictly anatomical perspective on organisms, nor one appealing to an immaterial vital principle, including the soul. Rather, the vitalist interest here is on the type of articulation of the parts in an organism: both the specificity of the relation between the parts, and indeed the specificity of the material properties of these parts (i.e. the organs) themselves.

Enlightenment vitalism is different from vitalism as understood by (or rather feared by) the mainstream philosopher of biology or biologist (an understanding to which we return below) because it is more of an attempt to model the organizational, systemic properties of organisms than a positing of animas or immaterial life-forces, the latter implying a form either of overt substance dualism (e.g. soul vs. body, in which the soul is the life principle) or at least an argument that differentiates between living and non-living, or organic and inorganic systems, on the basis of a substantial difference. Vitalism is then a concept, or perhaps a family of concepts, implicated in a series of tensions and quarrels for legitimacy in the self-definition of the biomedical sciences. In addition, it seems to come in more or less metaphysical forms. We then need to achieve some conceptual clarity regarding this diversity, and to inquire into its metaphysical status.

16 von Bertalanffy 1933, 48 (he expands on the idea of the organism as a system of relations on the next page). 


\section{Saving Vitalism (and Materialism) from Metaphysics: Entelechy and Atom}

We have already encountered Crick's dismissive attitude towards vitalism - in his case, Driesch's vitalism - in his 1966 book. ${ }^{17}$ In the following year this book was reviewed by the distinguished biologist C.H. Waddington in Nature. In response to Crick's aggressive claim, Waddington raised the following question concerning "odd" entities in modern physics: "Is a quark included? And if biologists should find it necessary to postulate an entity as odd as a quark, would that be vitalistic or not?"18 Among physicists the status of the quark is still a controversial topic. In general, a quark is postulated as a more "fundamental" constituent of matter. Yet in some sense it is legitimate for Waddington to claim that a vital agent such as Driesch's entelechy, upon first impression, is as odd as a quark. This is easy to understand. Driesch's doctrine of the entelechy was widely cited (and then dismissed). ${ }^{19}$ For Driesch, an entelechy is a non-material vital agent which is partly responsible for some organismic functions. Importantly, the entelechy, studied exclusively in biology, makes biology essentially irreducible to physics and chemistry. But the entelechy, according to Driesch, is invisible and thus inaccessible to sense experience. In like manner, a quark is also unavailable to direct observation. However, we know that physicists could insist that the quark exists, while present biologists are not allowed to do the same with the entelechy.

If the existence of the quark is still a controversial matter in modern physics, the reality of the atom is undisputed. In fact, in the eyes of modern biologists and philosophers of biology, the affirmed existence of the atom in modern physics implicitly supplies the strongest ground to dismiss vitalism as a metaphysical heresy, from which biologists are supposed to distance themselves in order to secure biology as a respectable science, and this concerns a metaphysical or ontological belief about the ultimate constituents of the world. According to Ernst Mayr, modern biologists do not oppose what he terms "constitutive reduction," which

17 Crick 1966, 99.

18 Waddington 1967, 203.

19 Driesch 2002 [1905]. 
suggests that biological phenomena, events, and processes are merely "the constituents of which they are composed."20 More explicitly, with a specific reference to vitalism, the philosopher of biology David Hull asserts that "both scientists and philosophers take ontological reductionism for granted. Vitalism is dead. Organisms are 'nothing but' atoms, and that is that." 21

We do not know how many scientists and philosophers implicitly presuppose this metaphysical belief. But seen from the case of Mayr and Hull, this belief is quite influential and appears to decisively expel vitalism from the biological realm. Let us term this belief metaphysical materialism, which indicates that the ultimate constituents of the world are atoms (or materialistic entities) and nothing else. It is obvious that this formulation contradicts, and consequently leaves no room for vitalism, which claims on the contrary that in the biological realm organisms are governed by entelechies.

The reasons for rejecting vitalism are clear, and the gist is that metaphysical materialism is presupposed, rather than defended with solid arguments, as the correct account of the world. But could we argue for metaphysical materialism? In the first place, metaphysical materialism seems closely connected with human intuition. Human beings encounter material objects in the spatial-temporal world. We are familiar with the table used in daily life, and intuitively take it as an inalienable part of the world. on the basis of this intuition plus some modern physical knowledge it is then suggested that the table has atoms, exclusively, as its micro-constituents. Moreover, it is somehow further asserted that not only material objects, but also biological and even psychological objects are nothing but atoms and their micro-configurations. Through these bold assertions, metaphysical materialism builds itself as the dominating worldview, which claims to have captured the ultimate constituents of the world and in principle is able to make sense of everything else.

However, at first sight metaphysical materialism is hardly compatible with modern physics, even though it embraces some of its basic concepts

\footnotetext{
20 Mayr 1988, 11.

21 Hull 1981, 282.
} 
such as the atom. In modern physics it is not clear how concepts such as field, energy, and force could receive adequate materialist interpretations ${ }^{22}$. In response to this defect, the more popular version of materialism in metaphysics today is termed physicalism. ${ }^{23}$ Now, like materialists, physicalists also make assertions about the ultimate constituents of the world. This time it is stated that everything in the world is nothing but physical in nature. Even though in the non-physical sciences it is unclear how their concepts can be reduced or even related to the ultimate physical constituents, metaphysicians still strongly believe that since they hold the ultimate in hand, concepts currently used in non-physical sciences and new concepts postulated in all sciences will finally turn out to be or at least build on physical concepts anyway. The logical empiricist Herbert Feigl is quite clear about this strategy: "the game of the radical physicalists" is "that whatever they deal with turns out to be physical!"24

Yet these metaphysical claims are at odds with scientific practice. Metaphysically-minded philosophers do not bother themselves with the sciences or their historical progress. Just because of this, their negative claims against vitalism are not at all adequate in the eyes of logical empiricists and scientific philosophers. In the rest of this section we propose a different, non-metaphysical manner of comprehending these issues concerning vitalism and materialism. This new perspective has logical empiricists (and some early twentieth century biologists) as its adherents and shares little interest in postulating the ultimate constituents of the world.

First, logical empiricists dismiss metaphysics as raising meaningless questions. For logical empiricists, traditional metaphysics makes claims about the ultimate constituents of the world, yet these claims largely remain at the speculative level with little empirical evidence. This attitude applies to metaphysical versions of both vitalism and materialism. Concerning materialism, Feigl complains that "science is still identified with an absurd mechanistic reductionism." ${ }^{25}$ Another logical empiricist and

\footnotetext{
22 Wolfe 2016, 129.

23 Ney 2008.

24 Feigl 1971/1981, 364-365.

25 Feigl 1949/1953, 8.
} 
physicist, Philipp Frank, also criticized idle formulations of metaphysical materialism. Concerning the concept of the atom, Frank claims that "matter and atom" are merely auxiliary concepts in modern physics, but these concepts are mis-applied to "everything in the world."26

Second, as a result, for logical empiricists it is not legitimate to reject vitalism by presupposing metaphysical materialism, which is meaningless in itself. In other words, it is legitimate, at least at the early stage of advancing hypotheses, to invoke materialistic as well as vitalistic concepts. Therefore, at the hypothetical level both the atom and the entelechy should be permitted. This attitude is supported by major logical empiricists, who never take Driesch's doctrine of the entelechy as a metaphysical heresy. For instance, Frank claimed that Driesch's introduction of the entelechy into biology "certainly means going beyond the frame of physical laws, but in no way an abandonment of the ground of empirical science." 27 Frank also wrote extensively on vitalism. Despite his later criticisms, in his early years Frank even felt obliged to support vitalism against metaphysical materialism [mechanism], claiming that:

"To be sure, Driesch shows that we can assume for the living processes a specific state variable, not that we must. For it is not possible to foresee every trick that one might invent in the fiction of hidden combinations of inorganic state variables. In favor of vitalism I should like to remark that, just as I cannot force someone who regards heat as a specific state variable to consider it as a motion of particles, so I cannot force the adherents of entelechy to replace it by fictitious state variables." 28

Here Frank anticipates the strategy used by metaphysical materialists: for whatever biological phenomenon, the causes are to be found among "inorganic state variables" such as the atom. Frank dismisses this strategy as illegitimate, merely relying on a verbal trick. An "inorganic state variable" remains fictitious, until one demonstrates how it causes biolog-

\footnotetext{
26 Frank 1949, 74.

27 Frank 1932 [1998], 111.

28 Frank 1908/1941, 26-27.
} 
ical change. Further, as Frank's final statement implies, in formulating hypotheses a truly scientific mind should be neutral towards materialistic and vitalistic concepts, and the latter could not be rejected by presupposing materialism. Overall, from the logical empiricist point of view, if one bothers himself/herself with the question of the ultimate constituents of the world, the postulate of the entelechy is as heretical as that of the atom; but in formulating hypotheses, the entelechy is as legitimate as the atom. In this way, Waddington's question can be satisfactorily answered by logical empiricists. Waddington is not mistaken in claiming that the entelechy is as odd as the quark. They are both hypothetical entities, the evaluation of which should be solely based on empirical evidence. To emphasize, naturally, the quark cannot appeal to materialist and physicalist metaphysics for its source of legitimacy. Similarly, in the case of vitalism, to paraphrase Alexander Gurwitsch, a distinguished biologist and contemporary of Driesch, "practical vitalism claims the right to be restricted in formulating hypotheses only by postulates of logic and of the general theory of knowledge, and by nothing else." 29

In sum, according to logical empiricism it is incorrect, as Bakhtin, Crick and many present biologists and philosophers do, to dismiss vitalism as a heresy because it violates materialist and physicalist metaphysics. It is also illegitimate to take atoms to be the ultimate constituents of the world, as if they grounded everything else, and discard entelechies because of this metaphysical bias. The final point to make about the logical empiricist perspective is that materialistic and vitalistic concepts are both legitimate at the hypothetical level, and their validity is only to be decided on the basis of later empirical evidence. The validity of materialistic and vitalistic concepts is an entirely different matter: it is solely relevant to the logic of science. Briefly, the history of science indicates that the concept of the atom has had great empirical success in modern physics since the nineteenth century; but the entelechy did not meet with similar success, and was finally discarded. Though space is lacking to elaborate the logic and the history, the legitimacy of the entelechy at the hypothetical level should now be clear, and we hope this section has indicated how vitalism (and materialism) could be saved from metaphysics.

29 Gurwitsch 1915, 765. 


\section{Synthetic Biology, Vitalism and the Definition of Life}

Vitalisms, as previous sections have shown, are various and do not necessarily entail metaphysical claims or the positing of immaterial life forces. More than a rebuttal, vitalism calls for a precise historico-philosophical characterization. In his Introduction to Canguilhem's The Normal and the Pathological, Foucault stressed a "paradoxical fact in the life sciences": while the "scientificization process is done by bringing to light physical and chemical mechanisms ... it has on the other hand, been able to develop only insofar as the problem of the specificity of life and of the threshold it marks among all natural beings was continually thrown back as a challenge." 30 To Foucault, this paradox however does not mean that vitalism is "true", but rather that it still plays "an essential role as an indicator in the history of biology": an indicator of problems to be solved (what constitutes the originality of life without constituting an independent empire in nature?), an indicator of reductions to be avoided (emphasizing the pervasiveness and necessity of concepts of preservation, regulation, adaptation). But what does happen to this heuristic value of vitalism when biology shifts away (or claims to) from its descriptive goal and turns to making life itself? When it explicitly challenges this supposed "specificity of life" and aims at overcoming this intuitive threshold? What are in this context the effects of the actual developments and achievements in synthetic biology - a discipline heavily relying on a machine analogy - on vitalism? Does a synthetic approach to life dispel this supposed fecundity of vitalism?

In 1828 , whereas the use of vital forces ${ }^{31}$ was still massive in the recent field of organic chemistry to account for the difference between the living

30 Foucault 1991, 18.

31 After the Lavoisierian revolution in chemistry, physiologists and organic chemists attempted to understand the chemical changes that living bodies undergo notably by developing a research program aiming at increasing the knowledge on the nature and composition of substances of biological origin. However, those investigations showed that, from a chemical viewpoint, there was no difference between mineral and biological bodies: the same elements in certain cases would produce inorganic compounds, and in others organic compounds. Thus the question of the reason of biological organization arose, and vital force seemed a convenient and accurate answer to that debated issue. Note that the precise role and nature of vital forces - are they considered the real cause of biological organization or do they emerge from the chemical constituents? are they mere 
and the non-living at a molecular level ${ }^{32}$, the achievement of the synthesis of urea from ammonium cyanate by the German chemist Friedrich Wöhler seemed to put an end to vitalist speculations by showing that nothing in vital matter needed more than ordinary chemistry to be assembled. Although the narrative of this founding myth has been challenged by historians ${ }^{33}$, its very existence is not without relevance to us since it embodies the age-old conflict between biological and chemical sciences, the former having been repeatedly challenged by the reductionist claims of the latter. Vitalism, minimally defined as the commitment to the irreducible nature of living processes to a set of straightforward chemical reactions, nonetheless survived this first synthesis of an organic compound; its supporters argued that urea was not a genuinely vital substance, but merely an excretion ${ }^{34}$, whose chemical status lied somewhere between the organic and the inorganic. While, throughout the $19^{\text {th }}$ century, the boundary between complex molecules and the organized living system (at the cellular level) was considered impossible to cross artificially, it still remained a hotly debated topic and an object of speculation. In his Biologie synthétique Leduc for example stated that:

"When we know the physical underlying mechanisms for the production of an object or a phenomenon . . . it becomes possible to reproduce it .... and science becomes synthetic. Biology is a science like any other ... it has to be sequentially descriptive, analytic, and synthetic." ${ }^{35}$

More recently, in 2007, a Nature editorial described the development of synthetic biology (SB) as an "antidote" to "chronic vitalism." SB, whose name rightly evokes synthetic chemistry, inherited from artificial life ${ }^{36}$ as well as from bioinformatics and was developed by scientists trained

epistemological tools aiming at orienting research or real forces acting upon matter? is however disputed among historians. See Wolfe 2011, Richards 2000, Zammito 2012, Duchesneau 1997, Gambarotto 2018.

32 See for example Berzelius 1814.

33 Brooke 1968, Ramberg 2000, Tomic 2012.

34 See for example Müller 1834.

35 Leduc 1912.

36 Langton 1989. 
in engineering sciences such as Drew Endy. ${ }^{37}$ Using tools borrowed from those disciplines, SB relies on the rational design of bioparts (BioBricks ${ }^{38}$ ), or microorganisms (standardized biological chassis) and aims at conceiving and building biological systems endowed with basic robust and predictable functions. ${ }^{39}$ Gayon $^{40}$ has identified at least 7 different uses of SB in the literature, covering 4 fundamental meanings: the synthesis of artificial life (including the synthesis of analogs of living systems, such as physico-chemical or computational models), the artificial synthesis of life (the assemblage of living organisms by the assemblage of organic parts), the modification of existing organisms and the biological engineering of hybrid forms (molecular computation). Interestingly the first three trends explicitly refer to "life". While SB promises to tackle fundamental theoretical issues - such as the definition of life - with new experimental opportunities, it is obvious that all those trends do not presuppose the same epistemological roots, nor do they undertake the same research strategies. Described as an "umbrella term"41, SB actually gathers three heterogeneous streams of practice: 1 ) the engineering of genetic circuits with DNA-based construction ${ }^{42}, 2$ ) the engineering of entire genomes that introduce synthetic genomes within bacteria chassis ${ }^{43}, 3$ ) and bottom-up programs such as the quest for realizing protocells ${ }^{44}$. Tasks 1 ) and 2) seem to confront life directly: they aim to "domesticate", "redesign" or "direct" life for human and social purposes. As Endy ${ }^{45}$ puts it, SB seeks to "generate, transform or evolve biological systems in order to control or use them for concrete, biotechnological goals, with an immediate application in the world of human needs." In order to fulfill this domesti-

\footnotetext{
37 Lazebnik 2002, Endy 2005.

38 BioBricks are small DNA modules, i.e. standardized units of functions - coding sequences, regulatory elements, linker sequences, etc.

39 Endy 2005.

40 Gayon 2013.

41 O'Malley et al. 2008.

42 Smolke 2009.

43 Venter 2010, Gibson et al. 2010.

44 Rasmussen et al. 2009.

45 Endy 2005.
} 
cating task, SB explicitly relies on the three engineering $\mathrm{Rs}^{46}$ : Rationality, Robustness and Reliability, as opposed to the whimsicality, inconstancy, and variability found in natural systems. Here in order to realize their synthetic life forms bioengineers assume a given cellular machinery, therefore their engineering of genomes and of genetic circuits merely displace the vitalist challenge to biochemistry. On the contrary the protocell program, intends to construct not only genomes, but also the whole cellular system within which a genome becomes functional. For this purpose, it acknowledges some fundamental properties of life (such as metabolism, self-replication, heredity and evolvability). In this case, the challenges are no longer the constitution of a functional genome, which mostly relies on computing, but also the construction of a lipid membrane, likely to display all properties required for maintaining cellular homeostasis, thermodynamics stability, etc. ${ }^{47}$ What does it mean for vitalism in this context?

In the Nature editorial, vitalism is depicted as a disease, often fought by the assaults of chemical and physical sciences, but never completely eradicated by them. It strategically refers to the belief in a "qualitative difference" between inert and living matter as well as the intuition that "life appears when a threshold is crossed". In that respect vitalism would entail two minimal claims: 1) the idea that life constitutes a "natural kind", i.e a category that exists in nature, as opposed to human concepts; 2 ) the supposed irreducibility of living matter to its inert constituents. Depending on our understanding of what "irreducible" means - epistemological or ontological - one could in turn conclude to the impossibility of a transition from the inert to the living, or of the generation of life out of brute matter, and claim the necessity of immaterial vital forces in order to account for that apparition. It is doubtful whether this metaphysical and caricatural form of vitalism survived the development of biology in the $20^{\text {th }}$ century (aside from creationism, or its contemporary avatar, Intelligent Design), it rather seems - as argued in section I of the paper that if one were to speak of contemporary forms of vitalism, those would be compatible with physicalism and emphasize (instead of the existence

46 Pleiss 2006.

47 Ruiz-Mirazo \& Moreno 2013. 
of an ontologically distinct living matter) the complexities of living processes, their subtle organization and self-organization. ${ }^{48}$ Still, Nature's editorial narrow characterization of vitalism as a metaphysical stance is a classic rhetorical strategy amongst scientists and philosophers ${ }^{49}$ in order to dispel any form of vitalism. Strikingly, the Nature editorial identifies, in passing, the metaphysical form of vitalism described above with the many attempts made by scientists to define life, thus conflating the search for a definition of life and nonmaterial vitalism. We might then question the relevance of such a connection: does the search for a definition of life necessarily lead to (metaphysical) vitalism? And does synthetic biology successfully deflate this so-called vitalist intuition of an essence of life?

If the notion of life was relatively overlooked during the 1960-1990s, notably because of the groundbreaking work of molecular biology and the subsequent conviction that the secret of life lied in genetic information and in the existence of a genetic code through which it could be expressed ${ }^{50}$, it seems to have resurfaced with the development of a new peripheral discipline in the 1990s, namely astrobiology, and was subsequently reactivated in evolutionary biology, molecular biology, artificial life, and later, during the 2000s, synthetic biology. ${ }^{51}$ There is little doubt that through its engineering approach, in which it strives to fabricate living-systems from scratch, SB has dramatically contributed - among the disciplines cited above - to discard the idea of a frontier between the living and the inert..$^{52}$ In that respect, coupled with prebiotic chemistry and astrobiology, SB could be described as an experimental and synchronic approach to the diachronic and historical problem of the origin of life. The established possibility to synthetize, create and assemble genuinely living-systems by means of their components alone invalidates the ancient metaphysical form of vitalism that emphasized the irreducible nature of vital matter. By blurring the frontier between the inert and the

\footnotetext{
48 Varela 1979, Normandin and Wolfe 2013, Moreno \& Mossio 2015.

49 Bernard 1878, Nagel 1961, Hempel 1966.

50 Watson 2004.

51 Morange 2003, Machery 2012.

52 Rasmussen et al. 2009.
} 
living, SB ends up challenging the existence of the notion of life itself, even though it contradicts one of SB's major avowed goals: elucidate the nature of life. In line with François Jacob's famous statement according to which biologists no longer study "life" in the lab, but merely "analyze living systems, their structure, their function, their history," ${ }^{33}$ proponents of synthetic biology seem to have contributed to dismiss the adequacy of this fuzzy and confounding concept from biology.

From that vantage point, synthetic biology would be the achievement of a century-long effort made to discard the legitimacy of essentialism in empirical sciences. ${ }^{54}$ Since science, according to Popper, does not aim at knowing the true nature of things (their essence), but rather at describing and explaining their behavior with hypothetical universal laws, definitions themselves are useless to empirical sciences. Raising the question of the true nature of something (life, matter, etc.) is thus both misleading (it offers an erroneous conception of scientific tasks) and inefficient (it is source of sterility). True scientific knowledge does not derive from speculative definitions that strive to capture the essence of a thing, but from empirically testable hypotheses. Because it lacks the empirical grounding and the universal explanatory power that scientific concepts must display, the notion of life is not a scientific concept: it does not belong to hypotheses that strive to account for a given class of observable phenomena. Or if it does, it fails to grasp the universality it seeks, as argued by Cleland 55: "our current scientific understanding of life is too limited to support a theoretically useful tentative generalization about all life." In accordance with Popper's analysis of scientific activity, driven by empirically testable hypotheses and theories, Gayon ${ }^{56}$ argues that this lack of definition of the word "life" has deep historical roots, and relates to the history of biology itself, understood as the science that "studies all and only the different forms and manifestations of life." 57 The success of

\footnotetext{
53 Jacob 1971.

54 Popper 1945.

55 Cleland 2012.

56 Gayon 2010, 2011.

57 On the distinction between biology and natural history and the constitution of "life" as a scientific problem, see Foucault 1966.
} 
the term "biology" in the $19^{\text {th }}$ century ${ }^{58}$, Gayon argues, is less due to the attempts made by physiologists, physicians, zoologists, etc. to define "life" than to the development of general theories, able to encompass all the phenomena and beings that we intuitively classify under the word "life" (cellular theory, evolutionary theory, biochemistry and molecular biology ${ }^{59}$. Those sub-disciplines - while they never attempted to define "life" - have provided strong evidence that living beings share a number of properties that distinguish them from any other natural beings. If it could be tempting to conclude from there to the possibility of defining life itself, precisely by extracting the most general features encountered in those sub-disciplines (membranes and metabolism, reproduction and evolvability, etc.), Gayon warns philosophers and scientists that a definition of life can be nothing but stipulative, relative to a particular theory: "such a definition will always be conventional, and for this reason, the wisest attitude that we may have is to accept that it is open to change, in response to new knowledge."60 This, of course, recalls Pascal's definition of scientific definitions, ${ }^{61}$ that are to be understood as pragmatic and conventional tools precisely because they don't target the essence of things, but only the meaning words have in a given context for the individuals who use them.

Whereas a definition is a theoretical construction that aims at capturing the universal content of the term defined, an operational criterion more resembles a set of properties that an item has to realize/possess in order to belong to a given class of phenomena or objects. While the development of new disciplines - astrobiology, artificial life and origins of life $\mathrm{e}^{62}$ - has arguably in the past 20 years reactivated the need for a stipulative definition of life, and triggered considerable scientific and philosophical efforts ${ }^{63}$, this occurred as avenues to forge operational criteria

\footnotetext{
58 On the history of the word "biology" see Mc Laughlin 2002.

59 See Gayon 2004, 2008.

60 Gayon 2011.

61 See for example De l'esprit géométrique et de l'art de persuader, and the Lettre à Le Pailleur circa January 1648.

62 Bersini \& Reisse 2007.

63 Cleland \& Chyba 2002, Bedau 2010, Bryulants, Bartik \& Reisse 2010.
} 
rather than as attempts to seek an essential definition. Aside from the disputable feasibility and efficiency of such attempts, it is clear that they do not entail any commitment to the existence of life as an ontologically separate category. Moreover, from what precedes it is unclear whether scientists seek a genuine definition of life - be it stipulative - or simply a set of operational criteria that enable them to rightly classify an item. In that respect the NASA definition of life, "Life is a self-sustained chemical system capable of undergoing Darwinian evolution," is less a definition than a set of operational criteria aiming at distinguishing living forms from other natural beings.

It is noteworthy that SB tackles the question of the definition/ identification of life from a synthetic perspective. Unlike other biological disciplines, SB does not have an analytic approach to its object, but quite literally builds it. Doing so, it contributes to dissolve the border between the living and the non-living, advocating for continuity. This experimental challenge to the concept of boundaries: living - non-living, natural - synthetic is not the least service SB provided biology. We have already noted, in passing, the manifest paradox that affects SB: it seeks to increase our knowledge on life through its fabrication. Focusing on the rational making of novel organisms, SB explicitly refers to an epistemological tradition that seeks knowledge through fabrication: verum et factum convertuntur, as Giambattista Vico put it: the principle of maker's knowledge. Bioengineers embrace this epistemological assumption that relies on a mechanistic ground: knowing is tantamount to taking things to pieces and putting them back together ${ }^{64}$. The chemist Marcelin Berthelot ${ }^{65}$ had exposed the view that chemistry literally fabricates its object, and that chemists know it only insofar as they fabricate it. The object of knowledge becomes transparent to knowledge because it is made by humans' hands. Only a few SB papers don't quote Richard Feynman's famous adage: "What I cannot create I do not understand".

Two difficulties arise then. The first one concerns the narrative of SB itself and the discrepancy between what it does and what it says. For instance, SB contributes to blur the boundary between the living and the

64 Lazebnik 2002.

65 Berthelot 1860. 
non-living, triggering new efforts in the definition of life beyond categories, while it exalts its capacity to create novel organisms, i.e. while it acknowledges the very boundary it contributes to dispel. The second relates to the difference between natural and synthetic life forms. Since SB does not limit itself to dismantle existing organisms and to reconstruct them, but aims at creating objects that don't exist in nature ${ }^{66}$, it addresses life not only as we already know it, but as it could exist: it explores processes and organizational structures that are alien to evolved terrestrial life. In light of those two paradoxes, it may thus be argued that far from dismissing any form of definitional effort, SB forces us to undertake such an effort, in the light of its experimental outcomes. Exploring those continuums would only be an antidote to an immaterial and metaphysical form of vitalism. Functional vitalism as well as attitudinal, or epistemic, vitalism ${ }^{67}$, because they don't violate physicalism, are not dismissed by the development of SB, quite the contrary. They seem totally in accordance with the protocell research program, which seeks the conditions for self-organization, precisely by acknowledging fundamental features of living entities.

\section{Conclusion}

It is easy to reject vitalism as a metaphysical heresy. Yet the metaphysical criticisms of the most notorious form of vitalism, that is, Driesch's doctrine of entelechy, are far from fair. As we saw in section 3, Driesch never intended his vitalism to address a metaphysical point, so that surprisingly but consistently, logical empiricists turn out to be in agreement with Driesch, and they defend the right to take vitalism seriously until disconfirmed by empirical evidence. Does vitalism impact the history of life science, and how? An affirmative answer might seem to imply the possible "legitimization" or "normalization" of what was thought to be a marginal or scientifically superfluous movement (see Crick, Gilbert and Sarkar), by seeking to inscribe it in a narrative of the development of biological science. The possibility of such an inscription allows of both

\footnotetext{
66 Marlière 2009.

67 Wolfe 2011.
} 
a stronger and a weaker interpretation (as suggested via the example of Montpellier vitalism in section 2). The stronger case for vitalism is the sort made by partisans of e.g. theoretical biology whose anti-reductionism is very zealous - a kind of non-negotiable commitment. ${ }^{68}$ The weaker case is easier to defend, because it is less directly falsifiable. It includes the more functional form of vitalism and contemporary work on biological organization. The recursive claim that the synthesis of life (organic compounds in the case of the $19^{\text {th }}$ century, DNA-based constructions, entire genomes, or protocells in the context of synthetic biology) would definitely discard the inconsistency of vitalism, has proved unfounded, as discussed in section 4. It relies on a historical and philosophical misunderstanding of the complex nature of vitalism, that can only be captured by considering its multiple figures. If the synthetic approach obviously repudiates nonmaterial vitalism, it is nonetheless consistent with functional or organizational vitalism. Discussing the soundness of the pervasive mechanistic conception of life, and acknowledging the genuine features displayed by living beings not only question the validity of SB's epistemological ground, those vitalist queries are also of heuristic value for SB's own achievements.

\section{References}

Bachelard, G., 1938/2004, La formation de l'esprit scientifique, Paris: Vrin.

Bakhtin, M., 1992, Contemporary Vitalism (1926), translation in F. Burwick \& P. Douglass, eds., The crisis in modernism. Bergson and the vitalist controversy, 76-97. Cambridge: Cambridge University Press.

Bechtel, W. \& Richardson, R.C., 1998, Vitalism. Routledge Encyclopedia of Philosophy, 639-643. London: Routledge.

Bedau, M.A., 2010, An Aristotelian account of minimal chemical life. Astrobiology, 10(10), 1011-1020.

68 See the discussion of such thinkers, such as Robert Rosen, in Wolfe 2014. 
Bernard, C., 1878, Leçons sur les phénomènes de la vie communs aux végétaux et aux animaux, Paris, Baillière.

Von Bertalanffy, L., 1933, Modern Theories of Development. An Introduction to Theoretical Biology, trans. J.H. Woodger. London.

Berthelot, M., 1860, Chimie organique fondée sur la synthèse. Paris: Mallet-Bachelier.

Berzelius, J., 1845, Traité de chimie minérale, végétale et animale. Édité par Friedrich Esslinger et Ferdinand Hoefer. $2^{\text {nd }}$ French edition. Paris: Firmin-Didot frères.

Bichat, X., 1800, Recherches physiologiques sur la vie et la mort. Paris: Béchet.

Blackburn, S., 2003, Metaphysics, In Nicholas Bunnin, E. P. Tsui-James (eds.), The Blackwell Companion to Philosophy, Second Edition ( $1^{\text {st }}$ edition 1996), 61-89. London: Blackwell.

Brooke, J.H., 1968, Wöhler's Urea and its Vital Force - A Verdict from the Chemists. Ambix, 15, 84-114.

Bruylants, G., Bartik, K., Reisse, J., 2010, Is it useful to have a clear-cut definition of life? on the use of fuzzy logic in prebiotic chemistry. Origins of Life and Evolution of Biospheres, 40(2), 137-143.

Cleland, C.E. 2012, Life without definitions, Synthese, 185(1), 125-144.

Cleland, C.E., \& Chyba, C.F., 2002, Defining life, Origins of Life and Evolution of the Biosphere, 32(4), 387-393.

Crick, F.,1966, Of Molecules and Men. Seattle: University of Washington Press.

Driesch, H., 2012, Der Vitalismus als Geschichte und als Lehre (Leipzig, 1905). Reprint, Bremen.

Duchesneau, F., Cimino, G., eds., 1997, Vitalisms: from Haller to the cell theory. Firenze: Olschki.

Dupré, J., 2012, Processes of life: essays in the philosophy of biology, Oxford, Oxford University Press.

Endy, D., 2005, Foundations for engineering biology. Nature, 438(7067), 449-453. 
Feigl, H., 1953, The scientific outlook: Naturalism and humanism (1949). In H. Feigl \& M. Brodbeck (eds.), Readings in the philosophy of science, 8-1 8. New York: Appleton-Century-Crofts, INC.

Feigl, H., 1981, Some Crucial Issues of Mind-Body Monism (1971). In R. Cohen (ed.), Inquiries and Provocations, 351-365. Dordrecht: D. Reidel Publishing Company.

Foucault, M., 1976, Les Mots et les choses. Paris: Gallimard.

Foucault, M. 1991. Introduction, in G. Canguilhem, The Normal and the Pathological, ed. Robert S. Cohen, trans. Carolyn R. Fawcett, 7-24. New York: Zone Books.

Frank, P., 1941, The Law of Causality and Experience (1908). In Between Physics and Philosophy, 17-28. Cambridge, MA: Harvard University Press.

Frank, P., 1949, Modern Science and its Philosophy. Cambridge, MA: Harvard University Press.

Frank, P., 1998, The Law of Causality and Its Limits (1932) (M. Neurath and R. Cohen, trans., R. Cohen, ed.). Dordrecht: Springer.

Gambarotto, A., 201 8, Vital Forces, Teleology and Organization. Philosophy of Nature and the Rise of Biology in Germany. Dordrecht: Springer.

Gayon, J., 2004, De la biologie comme science historique. Sens public. http://www.sens-public.org/spip.php?article32.

Gayon, J., 2008, De la biologie à la philosophie de la biologie, In F. Monnoyeur (Ed.), Questions vitales: vie biologique, vie psychique, 83-95. Paris: Kimé.

Gayon, J., 2010, Defining life: synthesis and conclusions. Origins of Life and Evolution of the Biosphere, 40(2), 231-244.

Gayon, J., 2011 , Defining life: philosophical or scientific issue?, Leopoldina Nationale Akademie der Wissenschaften (ms.)

Gayon, J., 2013, Biologie de synthèse ou biotechnologie synthétique?, Forum "La biologie de synthèse existe-t-elle?", CNAM, April 25.

Gibson, D.G. et al., 2010, Creation of a Bacterial Cell controlled by a synthesized genome. Science, 329(5987), 52-56.

Gilbert, S. and Sarkar, S., 2000, Embracing complexity: organicism for the $21^{\text {st }}$ century. Developmental Dynamics, 219, 1-9. 
Gurwitsch, A., 1915, On Practical Vitalism, American Naturalist, 49, 763-770.

Hempel, C., 1966, Philosophy of Natural Science, Englewood Cliffs (NJ): Prentice Hall.

Hull, D., 1981, Philosophy and biology. In G. Fløistad (ed.), Contemporary philosophy: a new survey, 281-316. The Hague: Martinus Nijhoff.

Jacob, F., 1971, La logique du vivant : une histoire de l'hérédité, Paris, Gallimard.

Kirschner, M., Gerhart, J., Mitchison, T., 2000, Molecular "vitalism", Cell, 100, 79-88.S.A.

Langton, CG., 1989, "Artificial life" in CG. Langton (ed.) Artificial life $I$ (Proceedings of the first conference on artificial life, Los Alamos, September, 1987). Addison-Wesley, Redwood City.

Lazebnik, Y., 2002, Can a biologist fix a radio?-Or, what I learned while studying apoptosis, Cancer Cell, 2 (3), 179-82.

Luisi, P.L., 1998, About various definitions of life, Origins of Life and Evolution of the Biosphere, 28(4-6), 613-622.

Machery, E., 2012, Why I stopped worrying about the definition of life... and why you should as well, Synthese, 185(1), 145-164.

Marlière, P., 2002., The farther, the safer: a manifesto for securely navigating synthetic species away from the old living world, Syst Synth Biol., 3(1-4), 77-84.

Mayr, E., 1988, Toward a new philosophy of biology: Observations of an evolutionist. Cambridge: Harvard University Press.

Ménuret de Chambaud, J.J., 1765, "Observation (Gram. Physiq. Méd.)," in D. Diderot \& J. le Rond D'Alembert (eds.), Encyclopédie ou Dictionnaire raisonné des sciences, des arts et des métiers, XI, 313-321. Paris: Briasson.

Morange, M., 2003, La vie expliquée ? 50 ans après la double hélice, Paris: Odile Jacob.

Morange, M., 2010, The resurrection of life, Origins of Life and Evolution of the Biosphere, 40(2), 179-182. 
Moreno, A., Mossio, M., 2015, Biological autonomy. A Philosophical and theoretical enquiry. Dordrecht: Springer.

Müller, J., 1834, Handbuch der Physiologie des Menschen für Vorlesungen. Coblenz: Hölscher.

Nagel, E., 1961, The structure of science. Problems in the Logic of Scientific Explanation, London, Routledge-Kegan Paul.

Ney, A. 2008, Defining Physicalism, Philosophy Compass, 3(5), 1033-1048.

Normandin, S., Wolfe., C.T., eds., 2013, Vitalism and the scientific image in the Post-Enlightenment Life science, 1800-2010. Dordrecht: Springer.

O’Malley MA, Powell A, Davies JF, and Calvert J, 2008, Knowledge-making distinctions in synthetic biology, BioEssays, 30(1), 57-65.

Pascal, B., 1964-1992, CEuvres complètes, Texte établi, présenté et annoté par Jean Mesnard, édition du Tricentenaire, Paris: Desclée de Brouwer, Bibliothèque européenne.

Peterson, E.L., 2010, Holism and Evolution in Biology and Anthropology: the Challenge of Gregory Bateson and C. H. Waddington to Biological Orthodoxy, 1924-1980. PhD Dissertation, University of Notre Dame, Program in History and Philosophy of Science.

Peterson, E.L., 2017, The Life Organic: The Theoretical Biology Club and the Roots of Epigenetics, Pittsburgh: University of Pittsburgh Press.

Pleiss, J., 2006, The promise of synthetic biology, Applied microbiology and biotechnology, 73(4), 735-739.

Ramberg, P.J. 2000, The death of vitalism and the birth of organic chemistry: Wöhler's urea synthesis and the disciplinary identity of organic chemistry. Ambix, 47(3), 170-195.

Rasmussen, S., Bedau, M.A, Chen, L., Deamer, D., Krakauer, D.C., Packard, N.H., Stadler, P.F., 2009, Protocells, Bridging Nonliving And Living Matter, Cambridge: Cambridge University Press.

Richards, R.J., 2000, Kant and Blumenbach on the Bildungstrieb: A Historical Misunderstanding. Studies in History and Philosophy of Science Part C, 31(1), 11-32. 
Ruiz-Mirazo, K., Moreno, A., 2013, Synthetic Biology : Challenging Life in order to grasp, use or extend it, Biological Theory, 7(4), 376-382.

Schlick, M., 1953 [1925], Philosophy of Organic Life, in H. Feigl and M. Brodbeck (eds.), Readings in the Philosophy of Science, 523-536. New York: Appleton-Century-Crofts.

Smolke, D.C., 2009, Building outside of the box: iGEM and the BioBricks Foundation. Nat. Biotechnol., 27, 1099-1102.

Strawson, P.F., 1959, Individuals. London: Methuen.

Tomic, S., 2012, Les origines de la chimie organique au-delà du mythe fondateur Comptes Rendus Chimie, 15(7), 553-568.

Varela, F., 1979, Principles of biological autonomy. New York: Elsevier. Waddington, C., 1967, No vitalism for Crick, Nature, 216, 202-203.

Watson, J., 2004, The secret of life, New York: Alfred A. Knopff.

Wolfe, C.T., 2011 , From substantival to functional vitalism and beyond: animas, organisms and attitudes, Eidos, 14, 212-235.

Wolfe, C.T., 2014, Holism, organicism and the risk of biochauvinism, Verifiche, 43(1-3), 41-60.

Wolfe, C.T., 2015, Il fascino discreto del vitalismo settecentesco e le sue riproposizioni, in P. Pecere, ed., Il libro della natura, vol. 1: Scienze e filosofia da Copernico a Darwin, 273-299. Rome: Carocci.

Wolfe, C.T., 2016, Materialism: A Historico-Philosophical Introduction, Dordrecht: Springer.

Wolfe, C.T. and Terada, M., 2008, The animal economy as object and program in Montpellier Vitalism, Science in Context, 21(4), 537-579.

Wolfe, C.T. \& Wong, A. 2014, The Return of Vitalism: Canguilhem, Bergson and the Project of Biophilosophy. In G. Bianco, M. de Beistegui \& M. Gracieuse (eds.), The Care of Life: Transdisciplinary Perspectives in Bioethics and Biopolitics, 63-75. Lanham, MD: Rowman \& Littlefield International.

Wong, A., 2016, Critical Life: Bergson, Canguilhem and the Critical Investigation of Life and the Living, PhD, Department of Philosophy, Université de Liège. 
Metaphysics, Function and the Engineering of Life: the Problem of Vitalism

Zammito, J., 2012, The Lenoir Thesis Revisited: Blumenbach and Kant, Studies in History and Philosophy of Science Part C: Studies in History and Philosophy of Biological and Biomedical Sciences, 43(1), 120-32. 